\title{
English Influence on Linguistic Landscape of Modern Russian Cities
}

\author{
Svetlana Pitina ${ }^{1}$ \\ ${ }^{1}$ Department of Theoretical and Applied Linguistics, Chelyabinsk State University, Chelyabinsk, Russian \\ Correspondence: Svetlana Pitina, Department of Theoretical and Applied Linguistics, Chelyabinsk State \\ University, 129 Kashirinykh Brothers Street, Chelyabinsk, 454001, Russian. E-mail: sap.pitina@rambler.ru
}

\author{
Received: November 1, 2019 Accepted: November 25, 2019 Online Published: December 15, 2019 \\ doi:10.5539/ijel.v10n1p61 \\ URL: https://doi.org/10.5539/ijel.v10n1p61
}

\begin{abstract}
This paper provides an integral cognitive and language and cultural study of linguistic landscape diversity which is of a particular interest from the viewpoint of multilingualism expansion. The research aims to outline and analyze peculiarities of English influence on the modern urban space of Russian cities. This paper puts forward and confirms the hypothesis that English influence on linguistic landscape of the three modern Russian cities is a regular process in commercial place naming, that it is realized in various ways in different types of ergonyms to meet the demands of customers. Local city space is seen as a complex system from the point of view of language and cultural studies. Local urban naming is analyzed on the material of about 1,000 partially or completely anglicized names of language centers, tourist agencies and book shops of Yekaterinburg, Saint-Petersburg and Chelyabinsk retrieved from official websites. The data analysis has shown the existence of both general tendencies in forming urban commercial place names and realization of regional consciousness in naming. The findings prove that nomination processes in urban naming combine local and global tendencies. One of the main universal tendencies of naming is urban globalization realized in the English influence on the modern linguistic landscape in general and on the urban place names in particular. It is shown that English influence (Anglicization) is realized in glocalization, the coexistence of English and local characteristics of Russian urban place names. Anglicization tendencies and mechanisms include language fashion and creativity. The study reveals patterns of borrowing, codeswitching and language interplay. It is illustrated that blending, transliteration from English into Russian, usage of hybrid words and expressions are characteristic of the analyzed minor place names.
\end{abstract}

Keywords: linguistic landscape, anglicization, glocalization, commercial place name, transliteration, blending

\section{Introduction}

Urban multilingualism is a comparatively new phenomenon in present-day Russian language and cultural situation requiring comprehensive theoretical research of the existing data. Urban onomasticon is viewed in the paper as a part of a city space on the material of anglicized commercial place names of Saint-Petersburg, Yekaterinburg and Chelyabinsk that are formed with the help of complete or partial usage of English in the naming process. The choice of commercial place names of the above-mentioned cities is conditioned by their significant role in Russian economy (true of the three cities) and cultural importance (relevant of Saint Petersburg and Yekaterinburg). We suppose that the choice of urban minor place names reflects language fashion, the influence of separate languages, and local peculiarities of linguistic landscape. It is expected to prove in the paper that English influence on linguistic landscape of the three modern Russian cities is a regular process in commercial place naming, that it is realized in various ways in different types of ergonyms to meet the demands of customers.

The system of place names includes macro and micro place names. If the first part of this system is stable and rarely changes in many countries, it often undergoes renaming in Russia due to social transformations. If macro place names have been studied in detail, micro place names system have rarely become the object of linguistic analysis. It can be explained by structurally and semantically heterogeneous character of minor place names groups and by the lack of stability and consequent changes of such lexical formations.

Micro place names form a special onomastic lexical system that is outlined on the basis of the size of the naming object, the presence of the locative component in its meaning, the degree of the object recognition. City objects nomination forms an important part of micro place names in general and urban lexis in particular. Pitina and Urvantsev (2018) view urban onomasticon as "the ordered system of place names and urban place names" (p. 17). It is represented in the Russian language and culture by an open system of place names and minor place names 
characterized by rather frequent renaming, by the appearance of new minor place names conditioned by changes of the social order and transformations of economic relations followed by inevitable alterations both in the language policy of Russia in general and of the concrete region, and a separate residential place in particular. Urban minor place names are artificially created names of city objects. They form a socially and historically conditioned part of lexis. It is an open lexical system; stability and flexibility of its components depends on various internal and external factors. Lozovoi and Nazvanova consider external factors to be an important and decisive mechanism in commercial place names creation (p. 25).

\section{Literature Review}

Linguistic landscape study has been the research focus of many scientists in the Russian Federation and abroad. Landry and Bourhis (1997) introduced the generally accepted designation linguistic landscape to denote "the visibility and salience of languages on public and commercial signs" (p. 23), although the number of signs has increased. We agree with Gorter (2013) that the phrase multilingual cityspace is more precise in studying "the use of more than one language in urban settings" (p. 190). Gorter sums up the main developments in the field of linguistic landscape analysis focusing "on current research that illustrate main theoretical approaches and methodological development as key issues of the expanding field, in particular when applied in settings of societal multilingualism" (ibid, p. 190). Backhaus (2007) gives a comprehensive analysis of urban multilingualism in the language of Tokyo signs. A few scientific works are aimed at studying English language influence on linguistic landscape (Iwasaki, 1994; Kachru, 1994; Krykova, 2004; Samsonova, 2010, etc.).

The forces that shape linguistic landscapes in present-day urban settings, their influence on the wider social and cultural reality are investigated by Shohamy, Ben-Rafael and Barni (2010) through comparative case studies of the major world cities. Shohamy and Ghazaleh Mahajneh (2012) view linguistic landscape as a tool for interpreting language vitality, as a symbolic construction of public space by analyzing verbal and non-verbal peculiarities of shop signs, advertisements, graffiti and other forms of visuals including icons, QR (quick response) codes, etc. Matlovic (2004) studies transitivity of the town image and its intraurban structures in the era of post-communist transformation and globalization.

There are numerous theoretical and empirical studies of Russian urban lexis. Golomidova (2017) views the problems of modern local urban nomination and suggests a new strategy of creating urban names which is based on the correlation with the integral city image (pp. 185-203). Such an approach is justified for creating an attractive image of the city, avoiding the appearance of non-euphonic and repetitive names of the city objects, and systematizing local language policy in naming constantly emerging minor place names.

We agree with Prokurovskaia (1996) that urban onomastic space is the system of "onomasemes or minor place names nominating city objects taking into account their space characteristics, arrangement and status" (p. 23). Prokurovskaia widens the notion of minor place names including plane or planar (names of micro districts and other conventionally outlined parts of the city); linear (names of streets, bystreets, etc.); and point (names of various functional objects). Commercial place names refer to the latter type (ibid).

In the system of urban place names artificially created, names of urban commercial objects influenced by English are represented by a large number of structurally and semantically different ergonyms. Superanskaia (1973) was the first to classify commercial place names into real, which indicate the situation of an organization and the type of its services, and symbolic, which reflect its activity implicitly (p. 197).

In the Dictionary of Russian onomastic terminology, Podol'skaia (1998) gives a detailed definition of a commercial place name as "a personal name of a business group of people, including union, organization, establishment, corporation, society, institution..." (p. 151). The word 'firm' was not popular at the pre-perestroika time when the dictionary was published, otherwise it would have been added to the list.

Shimkevich outlines pragmatic commercial place names which directly influence the addressee, further subdividing them into informative (containing information about organization) and associative (causing positive associations of the recipients) ergonyms (Shimkevich, 2002). However, our argument is that all commercial place names are informative in various ways otherwise they become useless and fail to perform pragmatic function. Peculiarities of modern Russian minor place names and naming are productively studied by many Russian and foreign linguists. Theoretical basis of place names analysis, the principles of their classification are being worked out by Berezovich (2009), Issers (2017), Urazmetova and Shamsutdinova (2017), etc. Problems of local place naming are reflected in a number of PHD theses (Nosenko, 2007; Tanaeva, 2012; Trapeznikova, 2010, etc.). Sizova (2004) resorts to language and cultural approach in analyzing English, Russian and French urban place names attempting to prove that commercial place names reflect values and cultural peculiarities of ethnic communities that are conditioned not only by characteristic features of language systems but also by specificities 
of culture.

We agree with Remm (2011) that the city is a semiotic system, a complex sociocultural phenomenon where space and time are simultaneously parts of itself and parts of its conceptualisation. Being a part this semiotic system, commercial place names are open, unstable, and undergoing language fashion and foreign language influence on a larger scale in comparison with other urban minor place names. They reflect the established tendencies existing in a concrete linguocultural situation to realize concepts of space, place and object of the place naming picture of the world and language conscience of city inhabitants.

\section{Methods}

Integral approach to linguistic landscape study is of particular interest as it can apply actual data and technique of various branches of linguistics and humanitarian sciences. Such an approach to city space analysis makes it possible to view linguistic landscape as a part of the multilayered space picture of the world. Complex study of naming city space objects peculiarities implies the usage of cognitive, language and cultural methods to analyze both the linguistic landscape as a whole and to view separate constituents of the city space including urban minor place names forming city onomasticon. It is argued that city onomasticon should be researched in cognitive and language and cultural aspects because cognitive approach helps reveal city understanding on the level of consciousness of its inhabitants, while language and cultural approach actualizes general and national and cultural or local peculiarities of the space picture of the world on the example of a concrete city. Comparative language and cultural analysis are supposed to correlate precedent phenomena existing in one cultural situation with their interpretation in another culture. Structural analysis has been used in outlining the main types of word-building of completely or partially borrowed commercial place names. Semantic analysis has been applied in clarifying the meanings of hybrid words and phrases.

Data collecting has resulted in over one thousand completely or partially anglicized commercial place names of educational language learning centers, tourist agencies and book shops of Yekaterinburg, Saint-Petersburg and Chelyabinsk retrieved from official websites of corresponding commercial organizations by the method of continuous sampling.

\section{Results and Discussion}

\subsection{Study of Glocalization in Russian Commercial Place Names}

Modern city is firmly integrated into the country life which, in its turn, undergoes the influence of numerous external tendencies. One of the universal tendencies of the present period is urban lexis internationalization or globalization. Being an international language, English influences lexical systems of other languages worldwide. Such influence is known as internationalization or Anglicization (other variants are anglification, Englishization) (c.f. Iwasaki, 1994; Kachru, 1994, etc.). Anglicization is realized in the influence of English on the language of a large modern city in general and on the city onomasticon in particular. Anglicization of urban lexis in a concrete language and culture is the inevitable result of such influence accompanied both by direct borrowing from English and by specific mixture of English and local lexical units. It is understood in this paper as glocalization, the coexistence of global (English) and local components in Russian minor urban place names. Anglicized commercial place names are not an exception in this process. Glocalization is understood in the paper as a more exact notion than the notions internationalization and Anglicization. Glocalization (from "global" and "localization") was coined by Robertson to name interpenetrating global and local processes in society (Robertson, 1992). Moreover, Robertson was the first to use the term globalization. According to Kozhevnikov and Pashkevich (2005), in a wide aspect, glocalization is viewed in social and economical studies as a regional localism, a "regional answer to global processes", and "a combination of local and global interests and orientations", when globality "becomes not a unidimensional space but translocality, a measure of the growing closeness of global and local poles" (p. 11).

The largest number of anglicized commercial place names is registered in Saint Petersburg and Yekaterinburg. It can be explained by the larger city space of the two cities and their role as important cultural centers, with Saint-Petersburg being the cultural capital of Russia, Yekaterinburg the Ural capital. Repeating commercial place names are found in the three analyzed lexical systems. Anglicized commercial place names of Yekaterinburg and Saint Petersburg are often seemingly more creative compared to the corresponding Chelyabinsk ergonyms. The smallest amount of anglicized commercial place names is characteristic of book shops naming because the number of book shops is fewer compared to the number of other commercial organizations. Unfortunately, it reflects changes in preferences and hobbies of the Russian population resulting in the decrease of printed production. However, tendencies and mechanisms of anglicizing commercial place names of the three Russian cities mainly coincide in the analyzed examples. 
Borrowed English words in commercial place names (exsoergonyms) can be completely or partially assimilated in the local linguistic landscape: Форвард-Тур (forward-tour), Лингва Тревел (lingua travel). Commercial place names are either transliterated into Russian: Смайл тур (smile tour), Энджой Тревел (enjoy travel), Лайк Тревел (like travel), Голден Тур (golden tour), Даймонд Тур (diamond tour), Санрайз (sunrise), ДИСКАВЕРИ (discovery) or used in the original form: Happy Trip, Story \& Travel, Wings, Fun Holidays, Sunny Holiday, Travel Logic, All Travels, Paradise, Love Travel, Major-tour. English words can be included into hybrid endoergonyms: ЧелСити (Chelyabinsk city), IZЮM travel (raisins travel). English or transliterated constituent of anglicized commercial place names can precede or follow the Russian part of a hybrid name: Рус-Тревел ('Rus', abbreviation from "Russian" and "travel"), Урал-Ресорт (Ural resort), Артемий Тур (Artemij tour), Мегаполисъ-Тур (the outdated variant of spelling the first component "megapolis" and "tour"), Форм Курорm (form resort), Холидей-тур (holiday travel), Энджой Трэвел (enjoy travel), VIP Лента (VIP band).

English words and word combinations with mistakes in spelling and structure are sometimes used in the analyzed commercial place names: Brend, Befree, Like Travel, etc. Deliberate usage of the Latin alphabet in commercial place names, assimilation of the English noun "land" in ОЛорляндия can cause communication barriers. This commercial place name can be understood either as "the Land of Oz" or "the land of the naughty". However, mistakes in transliterating English words into Russian are seldom found in the names of book shops, language learning centers and tourist agencies. Mistaken anglicizing is characteristic mainly of the names of clothes shops, cafes and restaurants.

One must admit that complete or partial anglicizing has become a universal phenomenon in commercial place naming. It reflects both globalization - the general tendency to use English in the urban naming process, and glocalization - the local peculiarity to approach anglicizing creatively in the concrete linguistic landscape.

\subsection{Creativity Realization in Anglicized Commercial Place Names}

Various degrees of creativity can be traced in anglicized commercial place names. Book shops, language centers and tourist agencies are often headed by the graduates from the faculties of foreign languages whose knowledge of English is sufficient enough to avoid or minimize mistakes in using English words and word combinations to create commercial place names for their firms. However, the study of book shops and language centers names in the three cities has revealed that there are numerous recurring anglicized commercial place names. Ergonyms Yesbook, Yes Book, Onbooks, Bookshop - are frequently used to name book shops; ergonyms My English, Study English, English Club, Language study are chosen for language learning centers. Creativity is realized in such names only in different spelling. To exaggerate the importance of commercial structures is typical of Russian mentality. It is manifested in urban naming. Hyperboles are mainly used in commercial place names of language centers and tourist agencies: Planet English, World of English, World Travel, Euro Travel.

Creative commercial place names can be formed by compounding, abbreviation and blending. The resulting anglicized compounds-neologisms are not always clear even to native speakers of English: Studyland, Englishup, FasTrackEnglish, Booksandyou.ru, TouriStar, Inbookshop.ru. Semantic shifts can be traced in the local acronym of the language learning center DIY. The direct meaning of the name denotes independent learning of English, not in the educational center. Commercial place name Native Language is ambiguous, implying either immaculate knowledge of English after attending this center or the staff consisting of native English speakers. Educational commercial place name Diplomat presupposes teaching not only English but other languages of international communication and corresponding diplomatic manners and behavior. Precedent names including headlines of famous books, songs, and folklore heroes most often do not reflect the activity of commercial organization: Robin Good Consulting, Diplomat, Only уои, Заводной Апельсин (Clockwork Orange). Robin Good Consulting language learning center is a bright example of semantic shift as the name contradicts the target of the center to teach English, not to be consulted by the noble robber (in spite of the association with Robin Hood, however, there can be several interpretations of this commercial name, one of which is connected with the transliteration of Hood as $\Gamma y \partial$ into Russian and with back translation into English as Good).

In the name of a tourist club of extreme travels GoX3m one can find the mixed letter-digital English-Russian message sounding abbreviation $X 3 m$, where 3 is pronounced as a Russian numeral while letters $X$ and $m$ substitute adjective extreme in the one-piece represented imperative sentence Go extreme. This name is definitely not easily deciphered. Probably, it appeared to stress the dangerous nature of its touristic activity.

There are numerous examples of using both English and Russian words in one commercial place name: Mope Travel (either "sea of travel" or "more travel", if the first component is understood as transliteration into Russian of the English adverb more), Матрешка travel ("Russian doll" plus "travel"), МноGО туров (the first syllable of the Russian adverb много - many is combined with the English verb go in capital and the Russian noun туров), 
Pycb-trav (combination of poetic Pycb and colloquial trav has lead to the mixture of registers). In commercial place names БуквоедоедOff (pedant), Каляка \& Маляка (scribbles), Орел \& Решк@ (heads or tails) English functional parts of speech are inserted between Russian nouns or follow the Russian noun as in the first example. In phrases VIP Лента (VIP band) and Babykniga (babybook), Russian words follow English without changes in spelling or with transliteration into English in the new compound. Hybrid commercial place names contain English abbreviations and acronyms, functional and notional words, rhymed phrases, precedent names and phenomena. Analysis has proved that such hybrid names are typical of the local onomasticon as they illustrate linguistic creativity of commercial structure owners in the three cities.

Generalizing nouns travel and tour are most frequently found in touristic commercial names, while the words book and press are often used in the names of book shops. Generalizing nouns study, club, and school are typical of educational commercial place names. Specifying components of educational ergonym-phrases include English, excellent, perfect, elite, lucky; words education, my, new, VIP are frequently used in the names of book shops; tourist agencies often apply the words Coral, Diamond, Charm, Gold, Green to attract prospective customers.

Concretizing local commercial place name CHEmodan is both homophone and blending, composed of the first syllable of Chelyabinsk place name spelled in Latin and transliterated into English plus the Russian noun chemodan (suitcase) without the first syllable. Che is a shortened name of the city. It is spread among Chelyabinsk youth, but understood by all inhabitants of the city. Local commercial place names of Yekaterinburg Книгабург - city of books (composed of the Russian noun книга plus the place naming suffix -burg) and Прессбург - city of media (media plus the same place naming suffix -burg) contain the suffix with the clear local attribution (the popular colloquial name of Yekaterinburg is Eбург-Yeburg). These examples illustrate both hyperbolization and glocalization.

A number of anglicized commercial place names of tourist agencies are formed by ignoring the rules of English grammar in the elliptical sentence Like travel or combining the imperative sentence with the adjective: Go! Touristic.

Compounding, abbreviation and blending are the main types of creating anglicized commercial place names. The appearance and spread of mixed English-Russian and Russian-English examples of blending in the analyzed commercial place names reflects, on the one hand, the tendency of its owners to be original and creative in naming but on the other hand often results in misleading and funny sounding names of tourist agencies, book shops and language learning centers. Such commercial place names are intended mainly for Russian customers. Their owners erroneously suppose that ignoring the usage of Russian equivalents of English words and phrases will help to promote their business. Most often the result of creative naming is the opposite: hybrid commercial place names are often difficult to understand, they are frequently ambiguous and not euphonic. However, creative or not, commercial place names are often short-lived due to strong competition.

\subsection{Ways of Borrowing English Words and Phrases}

The analysis of the three groups of commercial place names has revealed that English words and phrases are used by complete or partial borrowing. Complete borrowing is represented:

1) By preserving English orthography: Family hobby bookshop, New Wallet, Happy Studies, Language Master, Teacher's Lab, Dorothy's, English Dog.

2) By using rhymed English word combinations in commercial place names to attract customers: Say and Play, Smart Start, Fine Line.

3) By applying English precedent names both in English and Russian spelling: 007, Камелот (Camelot), Биг Бен (Big Ben), Шалтай-Болтай (Humpty-Dumpty), Колумб (Columbus), Брайтон (Brighton), Маленькая Британия (Little Britain).

4) By complete or partial transliteration and transcribing of English words and phrases into Russian: Хеллоу (hello), Интеллиджент (intelligent), Спикинг and Спикин (speaking), Бэбибум (baby boom), ЛитлЛили (little Lily), Спик энд го (speak and go), Инджой (enjoy), Чиптрип (“cheap" plus "trip"). Transliterated personal names and place names are also popular in commercial place names: Алис-альянс (Alice alliance), Дядюика Ник (Uncle Nick), Лондон Стрит (London Street). English personal names can be either precedent: Робинзон (Robinson) or frequently used complete or shortened names: Ник (Nick), Дороти (Dorothy), etc. Well known English (mainly British) place names of cities and city objects are chosen as a rule to name language centers: Британия (Britain), Лондон (London), Оксфорд (Oxford), Кембридж (Cambridge), Биг Бен (Big Ben), etc.

5) By using functional parts of speech: articles, prepositions, conjunctions in English and mixed Russian-English words and word combinations: Onbooks, Эйн \& Штейн. Creative commercial names are formed by dividing 
famous family names and misleading possible customers as in Эйн \& Штейн (Einstein), or inserting conjunctions as in the Russian rhyming nursery phrase Каляка \& Маляка (scribbles) used in the singular instead of the plural, or the name of a popular TV program Орел\&Решк@ (heads or tails).

6) By various types of abbreviations: E-перевод (E-letter abbreviation of "English" plus "translation"), $A B C$, English Pro, Bis English, PM Study, DIY, LuckyU.

Partial borrowing from English is realized in Russian commercial place names by:

1) Blending English or transliterating Russian-English words: Labridge School, Kinglish, Фолэнг (foreign language). One can hardly find such blends in English dictionaries.

2) Compounding neologisms: Studyland, Англомир (English world).

3) Pseudo English words by writing Russian words and phrases in Latin alphabet: Bezzapinki (without hesitation), Perevodim.Pro (we translate professionally), ОБорляндия (Naughtyland) for pragmatic purposes.

The majority of borrowed English or anglicized words and phrases in commercial place names of book shops, travel agencies and language learning centers appear in linguistic landscape of the three cities by the same ways, but a concrete naming process can be unique, reflecting creativity, individual tastes, preferences and even the owners' level of English language education.

\section{Conclusion}

The analysis of local Russian commercial place names of Saint-Petersburg, Yekaterinburg and Chelyabinsk has proved that they undergo the influence of language fashion and glocalization, which is realized in the influence of English on their nomination. English influence on Russian city onomasticon has its own characteristic features in a concrete urban linguistic landscape due to the mixture of global and local traditions of naming city objects.

English influence on linguistic landscape of the three modern Russian cities is a regular process in commercial place naming; it is realized in various ways in different types of ergonyms to meet the demands of customers. The result of glocalization is the creation of original but often unjustified and ambiguous mixed English-Russian or Russian-English commercial place names, borrowing English words, and transliteration from English into Russian whether correct or not. Moreover, English influence often leads to a mixture of the form and content of the microtoponymic concepts verbalized in commercial place names. Commercial minor place names nomination process is mainly chaotic, difficult to regulate and standardize. The lack of stability in this lexical system often leads to the appearance of repetitive commercial place names in the image of the local city space, on the one hand, and to the formation of original and creative ergonyms in linguistic landscape of the modern city, on the other hand. Play of words, irony, mixture of styles, deliberate violation of the accepted norms of English orthography and grammar can frequently accompany realization of minor place concepts in the analyzed commercial place names.

The research of anglicized commercial place names on the material of the names of book shops, tourist agencies and language learning centers of the three large Russian cities has shown both the presence of general tendencies in naming and realization of regional consciousness in the local linguistic landscape. We suppose that further study of Anglicization in Russian commercial naming is actual and perspective because it is an evident present-day tendency, and it is a bright example of language fashion realization. Language fashion cannot be everlasting, but its influence on the native tongue is considerable.

Anglicization of Russian linguistic landscape should definitely be taken into account in teaching lexicology, social linguistics and cross-cultural communication enabling ESL students to understand universal tendencies and local peculiarities of naming processes.

Anglicized commercial place names represent only a part of multilingualism expansion. We hope that subsequent research of new data will confirm the hypothesis put forward in this paper that English influence on linguistic landscape of the city is a regular process.

\section{Acknowledgements}

Acknowledgement to the grant of Financial Support of Perspective Studies of Chelyabinsk State University, 04.03.2019, №126-1.

\section{References}

Backhaus, P. (2007). Linguistic landscapes: A comparative study of urban multilingualism in Tokyo. Clevedon, UK: Multilingual Matters. https://doi.org/10.21832/9781853599484

Berezovich, E. L. (2016). Russian place-name study in ethnolinguistic aspect: Space and human being (2nd ed.). 
Moscow: Knizhny dom «LIBROCOM».

Golomidova, M. V. (2017). Modern urban naming practices: strategic approaches and practical solutions. Voprosy Onomastiki, 14(3), 185-203. https://doi.org/10.15826/vopr_onom.2017.14.3.029

Gorter, D. (2013). Linguistic landscapes in a multilingual world. Annual Review of Applied Linguistics, 33, 190212. Cambridge University Press. https://doi.org/10.1017/S0267190513000020

Issers, O. S. (2017). Language and cultural bases of creative decisions in naming. Cognitive Studies of Language, 30, 821-824.

Iwasaki, Y. (1994). Englishization of Japanese and acculturation on English to Japanese culture. World Englishes, 134(2), 261-272. https://doi.org/10.1111/j.1467-971X.1994.tb00311.x

Kachru, B. (1994). Englishization and contact linguistics. World Englishes, 134(2), $135-154$. https://doi.org/10.1111/j.1467-971X.1994.tb00303.x

Kozhevnikov, N. N., \& Pashkevich, N. L. (2005). Glocalization: conceptions, characteristic features, practical aspects. Yakut State University Bulletin, 2(3), 111-115.

Krykova, I. V. (2004). English ergonyms trademarks of Japan as a reflection of national culture. PHD thesis synopsis on philology. Vladivostok.

Landry, R., \& Bourhis, R. Y. (1997). Linguistic landscape and ethnolinguistic vitality: An empirical study. International Journal and social Psychology, 16, 23-49. https://doi.org/10.1177/0261927X970161002

Lozovoi, A. Y., \& Nazvanova, I. A. (2013). On nomination problem. Modern Ergonym Peculiarities. Proceedings of Southern Federal University. Technical Sciences, 10(147), 25-30.

Matlovic, R. (2004). The transitive image of the town and its intra-urban structures in the era of post-communist transformation and globalisation. Sociológia, 36(2), 137-158.

Nosenko, N. V. (2007). City objects names of Novosibirsk: structural and semantic and communicative-pragmatic aspects. PHD thesis synopsis on philology. Novosibirsk.

Pitina, S. A., \& Urvantsev, G. V. (2018). Urban onomasticon in fiction and cinema discourse. Issues of Cognitive Linguistics, 11(411), 60-64. https://doi.org/10.20916/1812-3228-2018-1-17-23

Podol'skaia, N. V. (1988). Dictionary of Russian onomastic terminology. Moscow: Nauka Publ.

Prokurovskaia, N. A. (1996). City in the mirror of its own language: on the language material of Izhevsk. Izhevsk: Udmurtsky University Publ.

Remm, T. (2011). Understanding the city through its semiotic spatialities. Sign Systems Studies, 39(2/4), $124-144$. https://doi.org/10.12697/SSS.2011.39.2-4.06

Robertson, R. (1992). Globalization: Social Theory and Global Culture. London: SAGE Publications Ltd.

Samsonova, E. S. (2010). Functioning of foreign language means in commercial naming. Tomsk State Pedagogical University Bulletin, 6(96), 16-20.

Shimkevich, N. V. (2002). Russian commercial ergonomy: pragmatic and language and cultural aspects. PHD thesis on philology. Yekaterinburg.

Shohamy, E., Ben-Rafael, E., \& Barni, M. (Eds.). (2010). Linguistic landscape in the city. Bristol, UK: Multilingual Matters. https://doi.org/10.21832/9781847692993

Shohamy, E., \& Ghazaleh Mahajneh, M. A. (2012). Linguistic Landscape as a Tool for Interpreting Language Vitality: Arabic as a 'Minority' Language in Israel. In D. Gorter, H. F. Marten \& L. Van Mensel (Eds.), Minority Language in Linguistic Landscape. Palgrave studies in Minority languages and communities (pp. 89-106). Palgrave Macmillan, London. https://doi.org/10.1057/9780230360235_6

Sizova, E. A. (2004). Language and cultural analysis of place names: on the material of Russian, English and French languages. PHD thesis synopsis on philology. Piatigorsk.

Superanskaia, A. V. (1973). General theory of the proper name. Moscow: Nauka Publ.

Tanaeva, Z. T. (2012). Abbreviated ergonyms of Makhachkala as a multilevel system. PHD thesis synopsis on philology. Makhachkala.

Trapeznikova, A. A. (2010). Onomastic consciousness of the modern city dweller: on the material of Krasnoyarsk ergonymy. PHD thesis synopsis on philology. Krasnoyarsk. 
Urazmetova, A. V., \& Shamsutdinova, J. K. (2017). Principles of place names classifications. XLinguae Journal, 10(4), 26-33. https://doi.org/10.18355/XL.2017.10.04.03

\section{Copyrights}

Copyright for this article is retained by the author, with first publication rights granted to the journal.

This is an open-access article distributed under the terms and conditions of the Creative Commons Attribution license (http://creativecommons.org/licenses/by/4.0/). 